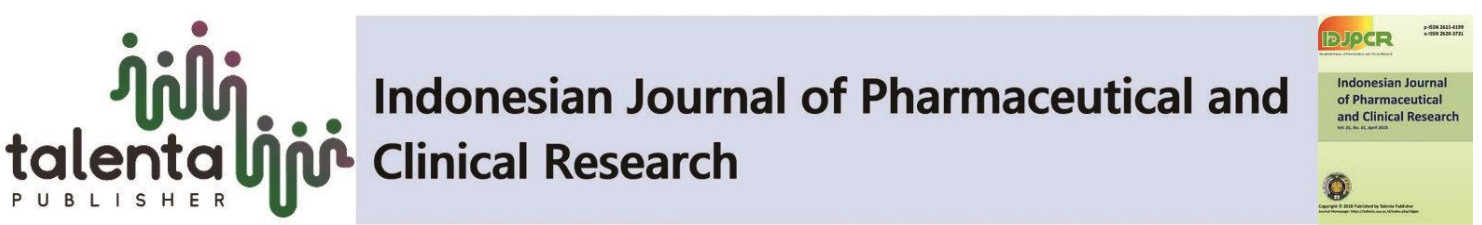

\section{Anti-Acne Activity From Biocellulose Mask Formula Containing (Aloe Vera (L.) Burm.F) Essence Combined With Vitamin $E$}

\author{
Raissa Fitri', Julia Reveny ${ }^{1^{*}}$, Urip Harahap ${ }^{2}$, Hariyadi Dharmawan \\ Syahputra ${ }^{3}$, Nasri Nasri ${ }^{4}$ \\ ${ }^{1}$ Department of Pharmaceutical Technology, Faculty of Pharmacy, Universitas Sumatera Utara, Medan, \\ Indonesia \\ ${ }^{2}$ Department of Pharmacology, Faculty of Pharmacy, Universitas Sumatera Utara, Medan, Indonesia \\ ${ }^{3}$ Department of Pharmaceutical Chemistry, Faculty of Pharmacy, Universitas Sumatera Utara, Medan, \\ Indonesia \\ ${ }^{4}$ Department of Pharmaceutical Biology, Faculty of Pharmacy, Universitas Sumatera Utara, Medan, \\ Indonesia
}

\begin{abstract}
Biocellulose mask sheet is a new found pharmaceutical cosmetic design that widely commercial. Mostly due to it's biodegradable properties, provide an eco-friendly waste. Combination of Aloe vera essence (AE) and Vit E to provide and determine it's respective anti-acne properties in biocellulose mask form. Formulation of biocellulose mask with the help of Acetobacter xylinum bacteria varied with different formulae: F1 (Vitamin E 1\%), F2 (E $2.5 \%), \mathrm{F} 3(\mathrm{AE} 5 \%), \mathrm{F} 4(\mathrm{AE} 2.5 \%+\mathrm{Vit}$ E $1 \%)$ and F5 (AE 5\%+Vit E 1\%) followed antimicrobials test with common acne bacteria by diffusion disk against Propionibacterium acne (PAC) ATCC 6919 and Pseudomonas aeruginosa (PAA) ATCC 27853. Study revealed that each formulae design F1; F2; F3; F4; F5 tested against PAC diffusion disk resulted $7.86 ; 11.67 ; 10.13 ; 112.10 ; 10.33 \mathrm{~mm}$ respectively. As for PAA diffusion disk resulted 7.76;11.63; 10.33; 11.67; $11.00 \mathrm{~mm}$ respectively. Biocellulose mask containing combination of aloe vera $2.5 \%$ with vitamin E (F4) would provide the best antiacne activity amongst other formulae.
\end{abstract}

Keyword: Acetobacter xyllinum, Anti-acne, Biocellulose mask, Essence, Propionibacterium acne, Pseudomonas aeruginosa

\begin{abstract}
Abstrak. Lembar masker bioselulosa adalah desain kosmetik farmasi baru yang ditemukan secara luas dan komersial. Sebagian besar karena sifatnya yang dapat terurai secara alami, dan menghasilkan limbah yang ramah lingkungan. Kombinasi Aloe vera (AE) dan Vit E memberikan sifat anti jerawat masing-masing dalam bentuk sediaan masker bioselulosa. Formulasi masker bioselulosa dengan bantuan bakteri Acetobacter xylinum divariasikan dengan formula yang berbeda: F1 (Vitamin E 1\%), F2 (E 2,5\%), F3 (AE 5\%), F4 (AE 2,5\% + Vit E 1\%) dan F5 (AE 5\% + Vit E 1\%) dan diikuti dengan uji antimikroba melalui disk difusi terhadap Propionibacterium acne (PAC) ATCC 6919 dan Pseudomonas aeruginosa (PAA) ATCC 27853. Studi menunjukkan bahwa masing-masing formula F1; F2; F3; F4; F5 diuji terhadap disk difusi PAC menghasilkan nilai hambatan masingmasing 7,86; 11,67; 10.13; 112.10; 10,33 mm. Sedangkan untuk disk difusi PAA menghasilkan 7,76; 11,63; 10,33; 11,67; $11.00 \mathrm{~mm}$ untuk masing-masing formula. Masker bioselulosa yang mengandung kombinasi lidah buaya $2.5 \%$ dengan vitamin $E$ (F4) memberikan aktivitas anti jerawat terbaik di antara formula lainnya.
\end{abstract}

\footnotetext{
*Corresponding author at: Universitas Sumatera Utara, Medan, Indonesia

E-mail address: julia.reveny@usu.ac.id
} 
Kata kunci: Acetobacter xyllinum, Anti-acne, Biocellulose mask, Essence,

Propionibacterium acne, Pseudomonas aeruginosa

Received 13 January 2021 | Revised 13 April 2021 | Accepted 28 April 2021

\section{Introduction}

Cellulose is one of the most biodegradable materials in nature. Biocellulose is a product of fermentation by the organism Acetobacter xylinum. Acetobacter xylinum produces biosellulose when grown in media containing carbon and nitrogen[1].

Sheet mask preparations are usually made of non-woven fabrics, paper fibers and biosellulose which are absorbed by essence. Sheet mask made using biocellulose obtained from natural sources such as bacteria. Bacteria are very attractive because of low toxicity and biodegradable properties to the environment. Acetobacter xylinum bacteria produce acid from glucose and synthesize cellulose. These bacteria create cellulose from glucose and related substrates through the pentose cycle. Cellulose obtained from Acetobacter xylinum bacteria has long and smooth fibrils, and shows good heat stability [2].

One of the skin diseases that are often suffered by humans is acne. Propionibacterium acne is a gram-positive rod-shaped bacteria and a normal flora of the skin that plays a role in formation of acne[3]. Propionibacterium acne converts unsaturated fatty acids into saturated fatty acids which cause sebum to become solid. If the production of sebum increases, more of the Propionibacterium acne will come out of the sebaceous glands, because Propionibacterium acne is a fat eater [4].

Aloe vera contains many useful substances such as polysaccharides, lignins, enzymes, vitamins, minerals, salicylic acid and amino acids. Mucopolysaccharides help in binding moisture into the skin. It has cohesive effects on the superficial flaking epidermal cells by sticking them together, which softens the skin. The amino acids can soften the hardened skin cells and zinc acts as an astringent to tighten pores. It also has anti-acne effect. Aloe vera has anti-bacterial and antiinflammatory properties that are good for treating acne[5].

\section{Material and Methods}

\subsection{Material}

Acetobacter xylinum stater, Old coconut water, Sugar, Acetic acid 20\%, Aloe vera, Vitamin E (dl $\alpha$-Tocopherol Acetate), Gylcerin, Polysorbate 80, PEG-40 Hydrogenated Castor Oil, Butylene glycol, Amonium sulfate, Xanthan gum, Sodium EDTA, Sodium Benzoate, Phenoxyethanol, 
Propionibacterium acne, Pseudomonas aeruginosa, Non-woven facial mask's shape, Distilled water, Foil bag, and Oleum citri.

\subsection{Preparation of biocellulose mask sheet}

The components of the biocellulose sheet mask preparation were shown in Table 1.

Table 1. Formula of biocellulose sheet mask

\begin{tabular}{ccc}
\hline No & Material & Amount 9g) \\
\hline 1 & Acetobacter xylinum starter & 10 \\
2 & Sugar & 4 \\
3 & Acetic acid & 2.5 \\
4 & Ammonium sulfate & 0.5 \\
5 & Old coconut water & 83 \\
\hline
\end{tabular}

\subsection{Making process}

Heat the old coconut water at $80^{\circ} \mathrm{C}$ for 15 minutes. Then let it cool down while added white sugar and ammonium sulfate. Acetic acid was added to the solution until it reaches $\mathrm{pH} 4$ After that, add acetobacter xylinum bacteria starter to the solution that has been cold, stirred homogeneously, put in a mold and covered with parchment paper to avoid contamination from the environment. The incubation process was carried out for $2-3$ days at $30^{\circ} \mathrm{C}$.

Bioclellulose which has been completed is taken out of the mold glass, washed with running water and cleaned the cucticle at the bottom of the biocellulose sheet. Boil it in boiling water for 30 minutes. After that, soaked in $0.5 \%$ hot $\mathrm{NaOH}$ solution for 15 minutes, washed in running water and soaked again with distilled water for 1 day to neutral $\mathrm{pH}$.

Cleaned and neutralized $\mathrm{pH}$ biocellulose sheet is placed on glass plates for the cutting shape of the face mask. The mask is then washed clean [6].

\subsection{Preparation of Aloe Vera Extract}

Fresh aloe vera were cultivated, washed and filleted. The gel were blended and filtered. The aloe vera extract then immediately put into the refrigerator[7].

\subsection{Preparation of Biocellulose Sheet Mask's Essence}

The components of the formulation were shown in Table 2. Tween 80 and PEG-40 hydrogenated castor oil was mixed with aloe vera extract and vitamin $\mathrm{E}$ until homogenized then glycerin was added (mixture 1). Xanthan gum was dispersed with butylene glycol (mixture 2). Sodium benzoate, metabisulfite, sodium EDTA and phenoxyethanol were dissolved in distilled 
water (mixture 3). Admixed mixture 2 and mixture 3 until homogenized (mixture 4), than slowly poured into mixture 1 until homogenized.

Table 2. Formula of biocellulose sheet mask's essence

\begin{tabular}{cccccccc}
\hline \multirow{2}{*}{ No } & Material & Fo & F1 & F2 & F3 & F4 & F5 \\
\hline 1 & Aloe vera extract & - & 1 & - & - & 1 & 1 \\
2 & Vitamin E & - & - & 2.5 & 5 & 2.5 & 5 \\
3 & PEG-40 Hydrogenated castor oil & 3 & 3 & 3 & 3 & 3 & 3 \\
4 & Tween 80 & 5 & 5 & 5 & 5 & 5 & 5 \\
5 & Glycerin & 5 & 5 & 5 & 5 & 5 & 5 \\
6 & Butylene Glycol & 1 & 1 & 1 & 1 & 1 & 1 \\
7 & Xanthan Gum & 0.2 & 0.2 & 0.2 & 0.2 & 0.2 & 0.2 \\
8 & Sodium Benzoate & 0.5 & 0.5 & 0.5 & 0.5 & 0.5 & 0.5 \\
9 & Phenoxyethanol & 0.3 & 0.3 & 0.3 & 0.3 & 0.3 & 0.3 \\
10 & Sodium Metabisulfite & 0.1 & 0.1 & 0.1 & 0.1 & 0.1 & 0.1 \\
11 & Sodium EDTA & 0.1 & 0.1 & 0.1 & 0.1 & 0.1 & 0.1 \\
12 & Oleum Citri & 5 drop & 5 drop & 5 drop & 5 drop & 5 drop & 5 drop \\
13 & Distilled water & 85.8 & 84.8 & 83.3 & 80.3 & 82.3 & 79.8 \\
\hline
\end{tabular}

\subsection{Packaging of Biocellulose Sheet Mask}

Before packaging process, biocellulose sheet mask was sterilized with autoclave in 30 minute at $121^{\circ} \mathrm{C}$ and cooled down until $30^{\circ} \mathrm{C}$. Packaging process had been done in laminar air cabinet (LAC), biocellulose sheet mask had layered with nonwoven sheet to hold the surface texture. The biocellulose sheet mask had hand pressed with two plate of thick glass to drained the water content in biocellulose sheet mask. Fold the biocellulose and put into foil bag, weighed $35 \mathrm{~g}$ essence mask and then poured into a foil bag. Sealed foil bag with sealing tools and label it.

\subsection{The Physical Characteristic Test of Formula}

\subsubsection{Biocellulose Mask Sheet Thick and Weight}

The biosellulose mask sheet that has been produced was evaluated in the form of thickness and wet weight and weight with an emphasis on the biosellulose mask. Measurement of the thickness of the biosellulose mask sheet using a micrometer screw. Measurement of the weight of the biosellulose mask sheet by weighing the wet weight and weight with an emphasis on the mask sheet. Thickness measurements and weight were carried out on three sheets of biosellulose masks, the results obtained were then averaged [8].

\subsection{2 pH Measurement of Biocellulose Mask Sheet}

The biosellulose mask sheet was immersed for 2 hours in $100 \mathrm{ml}$ distilled water at room temperature. The surface $\mathrm{pH}$ is then measured using a $\mathrm{pH}$ meter (Kedida). Measurements were made three times and mean values were used. 


\subsubsection{Essence Homogeneity test}

A certain amount of preparations were applied on a piece of glass or other suitable transparent material, preparations should show a homogeneous composition and no visible coarse grains.

\subsubsection{Essence Stability test}

Each formula were put into plastic pots. Furthermore, the observations are in the form of changes in consistency, color and scent at the time of the preparation is finished as well as in storage for 12 weeks at room temperature.

\subsubsection{Essence pH}

Determining $\mathrm{pH}$ of the preparation is done by using a $\mathrm{pH}$ meter (Kedida). Instrument must first be calibrated using $\mathrm{pH}$ neutral buffer solution $(\mathrm{pH}$ 7.01) and acidic $\mathrm{pH}$ buffer solution ( $\mathrm{pH}$ 4.01) until the instrument shows the $\mathrm{pH}$ values. Then, washed the electrode with distilled water then dried with paper towels. Place the electrode in the essence, $\mathrm{pH}$ of the essence appears in the display.

\subsection{Anti-acne Activity Test}

$0.1 \mathrm{ml}$ of inoculum was put into a sterile petri dish, after which $15 \mathrm{ml}$ of nutrient media were poured at $45-50^{\circ} \mathrm{C}$, then shaken the plate on the table surface so the media and bacterial suspense were evenly mixed. The solid media is placed on a paper holder that has been soaked (30 minutes) in essence, then incubated in an incubator at $35 \pm 2{ }^{\circ} \mathrm{C}$ for 24 hours, then the diameter of the inhibition area (clear zone) growth is measured around the calipers. The limit of the inhibition zone is considered effective if it has an inhibition zone diameter of 13-18 mm, weak below $9 \mathrm{~mm}$, moderate active $9-12 \mathrm{~mm}$, very strong above $18 \mathrm{~mm}$.

\section{Result and Discussion}

\subsection{Biocellulose Mask Sheet Thick and Weight}

The result from biocellulose mask sheet can be seen in Figure 1. It was obtained that the average thickness of wet biocellulose was $0.57 \mathrm{~mm}$, while the weight of wet biocellulose, and the weight with emphasis, were $71.57 \mathrm{~g}$ and $23.87 \mathrm{~g}$, respectively. The percentage of water absorption of biocellulose was $66.63 \%$.

\subsection{Biocellulose Mask Sheet pH}

The $\mathrm{pH}$ examination of the biocellulose mask sheet was 7.0. The $\mathrm{pH}$ obtained is within the permissible range of $\mathrm{pH}$ requirements, namely $\mathrm{pH} 5-8$ [6]. The value of $\mathrm{pH}$ should not be too acidic because it can irritate the skin whereas if the $\mathrm{pH}$ is too alkaline it can cause scaly skin.

\subsection{Essence Homogeneity Test}


The results of the homogeneity test of the biosellulose mask essence preparation showed that all the preparations did not show any coarse grains when the preparation was applied to transparent glass. This indicates that the preparations made have a homogeneous structure.

\subsection{Essence Stability}

The essence is physically stable during storage. The color of the preparation remained clear, the odor and shape did not change from the start of observation to storage for 12 weeks, so it could be concluded that the essence of the biocellulose mask was physically stable [9].

\subsection{Essence pH}

The $\mathrm{pH}$ examination of the essence was $5.53-6.16$. The $\mathrm{pH}$ obtained is within the permissible range of $\mathrm{pH}$ requirements, namely $\mathrm{pH} 5-8[6]$. The $\mathrm{pH}$ value should not be too acidic because it can irritate the skin whereas and if the $\mathrm{pH}$ is too alkaline it can cause scaly skin.

\subsection{Anti-acne Activity Test}

Table 3, antibacterial activity test of bioseluose mask preparation was carried out on six formula. The results of the bacterial activity test from F4 had the best inhibition zone diameter, $11.67 \mathrm{~mm}$ inhibition zone diameter for Pseudomonas aeruginosa and 12.10 inhibition zone diameter Staphylococcus epidermidis.

The content of aloe vera which has anti-bacterial properties is anthraquinone. Anthraquinone is an antibacterial compound whose working principle is the interaction of phenol compounds with bacterial cells[10].

Table 3. Testing for antibacterial activity

\begin{tabular}{ccccccccc}
\hline & \multicolumn{8}{c}{ Inhibition Zone Diameter $(\mathbf{m m})$} \\
\cline { 2 - 9 } Formula & \multicolumn{4}{c}{ Pseudomonas aeruginosa } & \multicolumn{4}{c}{ Propionibacterium acne } \\
\cline { 2 - 9 } & $\mathrm{P} 1$ & $\mathrm{P} 2$ & $\mathrm{P} 3$ & $\mathrm{X} \pm \mathrm{SD}$ & $\mathrm{P} 1$ & $\mathrm{P} 2$ & $\mathrm{P} 3$ & $\mathrm{X} \pm \mathrm{SD}$ \\
\hline F0 & 6.0 & 6.0 & 6.0 & $6.00 \pm 0.00$ & 6,0 & 6.0 & 6.0 & $6.00 \pm 0.00$ \\
F1 & 7.8 & 7.9 & 7.6 & $7.76 \pm 0.12$ & 7,9 & 8.0 & 7.7 & $7.86 \pm 0.12$ \\
F2 & 11.6 & 11.8 & 11.5 & $11.63 \pm 0.15$ & 11,9 & 12.1 & 12.3 & $11.67 \pm 0.20$ \\
F3 & 10.5 & 10.6 & 9.9 & $10.33 \pm 0.38$ & 10,2 & 10.0 & 10.2 & $10.13 \pm 0.12$ \\
F4 & 11.6 & 11.8 & 11.6 & $11.67 \pm 0.12$ & 11,5 & 11.8 & 11.7 & $12.10 \pm 0.15$ \\
F5 & 11.0 & 11.1 & 10.9 & $11.00 \pm 0.10$ & 10.1 & 10.5 & 10.4 & $10.33 \pm 0.21$ \\
\hline
\end{tabular}

\section{Conclusion}

Bioseulose mask containing aloe vera combined with vitamin $\mathrm{E}$ essence can be formulated into a face mask preparation and is stable for 12 weeks of storage. Biocellulose mask preparation which has the best anti-bacterial activity is a biosellulose mask containing $2.5 \%$ aloe vera extract combined with $1 \%$ vitamin E against Pseudomonas aeruginase and Propionibacterium acne. 


\section{Acknowledgement}

The authors are gratefully thank to Faculty of Pharmacy University of Sumatera Utara for providing the technical facilities.

\section{REFERENCES}

[1] P. Perugini, M. Bleve, F. Cortinovis, and A. Colpani, "Biocellulose masks as delivery systems: A novel methodological approach to assure quality and safety," Cosmetics, vol. 5, no. 4, 2018, doi: 10.3390/cosmetics5040066.

[2] T. Amnuaikit, T. Chusuit, P. Raknam, and P. Boonme, "Effects of a cellulose mask synthesized by a bacterium on facial skin characteristics and user satisfaction," Medical devices : evidence and research Res., vol. 4, no. 1, pp. 77-81, 2011, doi: 10.2147/MDER.S20935.

[3] R. A. Bojar and K. T. Holland, "Acne and Propionibacterium Acnes," 2004, doi: 10.1016/j.clindermatol.2004.03.005.

[4] A. L. Perry and P. A. Lambert, "Propionibacterium acnes," Letters in Applied Microbiology, vol. 42, no. 3, pp. 185-188, 2006, doi: 10.1111/j.1472765X.2006.01866.x.

[5] D. G. S. Amar Surjushe, Resham Vasani, "Aloe Vera: A Short Review," Indian Journal of Dermatologyvol. 53, no. 4, pp. 163-166, 2008, doi: 10.4103/0019.

[6] J. Reveny, J. Tanuwijaya, and M. Stanley, "Formulation and Evaluating Anti-Aging Effect of Vitamin E in Biocellulose Sheet Mask," International Journal of ChemTech Research., vol. 10, no. 1, p. (322-330), 2017.

[7] J. Reveny, Surjanto, J. Tanuwijaya, and C. Lois, "Formulation of aloe juice (Aloe vera (L) burm.f.) sheet mask as anti-aging," International Journal of PharmTech Research., vol. 9, no. 7, pp. 105-111, 2016.

[8] P. Perugini, M. Bleve, R. Redondi, F. Cortinovis, and A. Colpani, "In vivo evaluation of the effectiveness of biocellulose facial masks as active delivery systems to skin," Journal of Cosmetic Dermatology. vol. 19, no. 3, pp. 725-735, 2020, doi: 10.1111/jocd.13051.

[9] G. Pacheco et al., "Bacterial cellulose skin masks-Properties and sensory tests," Journal of Cosmetic Dermatology, vol. 17, no. 5, pp. 840-847, 2018, doi: $10.1111 /$ jocd.12441.

[10] X. Guo and N. Mei, "Aloe vera: A review of toxicity and adverse clinical effects," Journal of Environmental Science and Health Part C Environmenta, vol. 34, no. 2, pp. 77-96, 2016, doi: 10.1080/10590501.2016.1166826. 